Article

\title{
Re-Potentiation of $\beta$-Lactam Antibiotic by Synergistic Combination with Biogenic Copper Oxide Nanocubes against Biofilm Forming Multidrug-Resistant Bacteria
}

\author{
Ruby Celsia Arul Selvaraj ${ }^{\circledR}$, Mala Rajendran * and Hari Prasath Nagaiah $(\mathbb{0}$ \\ Mepco Schlenk Engineering College, Sivakasi 626005, Tamil Nadu, India \\ * Correspondence: maalsindia@mepcoeng.ac.in; Tel.: +91-04562-235173
}

Received: 28 July 2019; Accepted: 20 August 2019; Published: 22 August 2019

check for updates

\begin{abstract}
Biofilm-associated tissue and device infection is a major threat to therapy. The present work aims to potentiate $\beta$-lactam antibiotics with biologically synthesized copper oxide nanoparticles. The synergistic combination of amoxyclav with copper oxide nanoparticles was investigated by checkerboard assay and time-kill assay against bacteria isolated from a burn wound and a urinary catheter. The control of biofilm formation and extracellular polymeric substance production by the synergistic combination was quantified in well plate assay. The effect of copper oxide nanoparticles on the viability of human dermal fibroblasts was evaluated. The minimum inhibitory concentration and minimum bactericidal concentration of amoxyclav were $70 \mu \mathrm{g} / \mathrm{mL}$ and $140 \mu \mathrm{g} / \mathrm{mL}$, respectively, against Proteus mirabilis and $50 \mu \mathrm{g} / \mathrm{mL}$ and $100 \mu \mathrm{g} / \mathrm{mL}$, respectively, against Staphylococcus aureus. The synergistic combination of amoxyclav with copper oxide nanoparticles reduced the minimum inhibitory concentration of amoxyclav by 16 -fold against $P$. mirabilis and 32-fold against $S$. aureus. Above $17.5 \mu \mathrm{g} / \mathrm{mL}$, amoxyclav exhibited additive activity with copper oxide nanoparticles against P. mirabilis. The time-kill assay showed the efficacy of the synergistic combination on the complete inhibition of P. mirabilis and S. aureus within $20 \mathrm{~h}$ and $24 \mathrm{~h}$, respectively, whereas amoxyclav and copper oxide nanoparticles did not inhibit $P$. mirabilis and $S$. aureus until $48 \mathrm{~h}$. The synergistic combination of amoxyclav with copper oxide nanoparticles significantly reduced the biofilm formed by $P$. mirabilis and S. aureus by $85 \%$ and $93 \%$, respectively. The concentration of proteins, carbohydrates, and DNA in extracellular polymeric substances of the biofilm was significantly reduced by the synergistic combination of amoxyclav and copper oxide nanoparticles. The fibroblast cells cultured in the presence of copper oxide nanoparticles showed normal morphology with $99.47 \%$ viability. No cytopathic effect was observed. Thus, the study demonstrated the re-potentiation of amoxyclav by copper oxide nanoparticles.
\end{abstract}

Keywords: amoxyclav; burn wound; fibroblasts; Tamarindus indica; urinary catheter

\section{Introduction}

Biofilm is a community of bacteria that survives like multicellular organisms. The biofilm phenotype is different from planktonic cells [1]. Biofilm forms through a complex cascade of events that encapsulate bacteria within self-assembled extracellular polymeric substances (EPS) [2]. Approximately $65 \%$ to $95 \%$ of biofilm is composed of water. The EPS of biofilm are made up of proteins $(\geq 2 \%)$, carbohydrates $(1-2 \%)$, and DNA $(\leq 1 \%)$ [3]. It is a viscous layer that prevents the entry of chemotherapeutic agents, leading to the recalcitrance of bacteria [4]. Bacteria inside the biofilm are resistant to external stress and evade the host immune system [5]. The therapeutic failure of antibiotics in the treatment of tissue and medical device-associated infections is mainly due to persistent biofilm formation. About $80 \%$ of recalcitrant infections are due to biofilm [6]. 
Biofilm-associated tissue infections are the sole cause of nosocomial infections [7], periodontitis [5], tooth decay [8], endocarditis [9], pulmonary infections [10], osteomyelitis [11], cystic fibrosis [12], tuberculosis [13], etc. Implantable and non-implantable medical devices are infected by bacteria. They establish biofilm on devices like contact lenses [14], intravenous catheters [15], breast implants [16], orthopedic implants [17], voice prostheses [18], cardiac valves [19], shunts [20], urinary catheters [15], dialysis units [21], ventricular assisted devices [22], etc. Infections caused by biofilm are responsible for high rates of morbidity and mortality. Biofilm architecture, stages of biofilm formation, and device-associated infection were reviewed by Algburi et al. [23].

Chronic wounds are a silent epidemic affecting millions of people globally. Among chronic wounds, burn wounds deserve special attention because of the extensive damage caused by heat. This type of wound is a major cause of mortality and morbidity [24]. Patients who are hospitalized for long periods void urine through urinary catheters [14], and long-term use of indwelling urinary catheters can cause urinary tract infections [25]. Biofilm formation by uropathogens is the most common cause of persistent infection in the genitourinary tract [26].

The post-antibiotic era is witnessing the co-evolution of pathogens resistant to antibiotics [27]. Even after the discovery of many diverse classes of antibiotics, $\beta$-lactam makes up $65 \%$ of the antibiotic market [28]. $\beta$-lactam antibiotics are widely used for a wide range of treatments, from simple boils and fever to the most complicated and life-threatening diseases, such as pneumonia, gonorrhea, meningitis, etc. [29]. Sales of $\beta$-lactam antibiotics amount to about $\$ 15$ billion [30]. These antibiotics are broad-spectrum agents, which makes them the first choice to ward off infection. Bacteria develop resistance to antibiotics due to their improper use [31].

Bacteria synthesize $\beta$-lactamase and cleave $\beta$-lactam rings [32]. To overcome this challenge, scientists have used $\beta$-lactam antibiotics together with $\beta$-lactamase inhibitors, such as clavulanic acid (amoxyclav) [33], sulbactam (ampicillin/sulbactam) [34], and tazobactam (piperacillin/tazobactam) [35]. Amoxicillin combined with the $\beta$-lactamase inhibitor clavulanic acid was initially effective against a broad spectrum of bacteria [33]. The clinical efficacy and safety of amoxicillin/clavulanic acid were compared with those of clindamycin in the treatment of odontogenic infections in a phase IV clinical trial $[36,37]$. The study reported that amoxyclav was not inferior to clindamycin in its efficacy and safety. A study by Assimakopoulos et al. [34] evaluated the clinical efficacy of ampicillin/sulbactam in patients in the intensive care unit suffering from ventilator-associated pneumonia caused by pandrug-resistant Acinetobacter baumannii. The study concluded that the combination of ampicillin and sulbactam was highly effective against pneumonia [34]. Shirley [36] examined the clinical efficacy of ceftazidime/avibactam and meropenem for the treatment of hospital-acquired and ventilator-associated bacterial pneumonia in a phase III clinical trial and demonstrated the clinical success of ceftazidime/avibactam. However, after a few years of extensive use, bacteria developed recalcitrance to $\beta$-lactamase inhibitors (clavulinic acid, sulbactam, avibactam, and tazobactam), as these inhibitors have an integral $\beta$-lactam ring, which is also cleaved by $\beta$-lactamase, resisting their combination. The prevalence of multidrug resistance among bacteria is due to the single target and single mode of action of antibiotics [33]. The rapid spread of multidrug resistance is due to the horizontal transfer of resistance genes between bacteria. Biofilm is the community of heterogeneous organisms where gene transfer is very easy [38].

One way to circumvent this phenomenon is to re-potentiate the antibiotics by using synergistic combinations with other antibiotics or with natural phytochemicals, such as thymoquinone, a benzoquinone [39] or pterostilbene, a polyphenol [40], which possess medicinal properties. The synergistic combination of more than one drug extends the sensitivity of pathogens to antimicrobial agents, reduces the toxicity of high doses of any single agent, and reduces the chance of developing resistance by acting on multiple targets of bacteria. Recently, metal oxide nanoparticles, such as silver [41] and copper [42], have been used to augment the efficiency of antibiotics. Copper oxide nanoparticles ( $\mathrm{CuO}$ NPs) are biocompatible and effective against pathogens. There are many methods of synthesizing $\mathrm{CuO}$ NPs, such as microwave irradiation [43], sonochemical irradiation [44], etc. 
Among the many methods available for synthesizing copper nanocubes, green synthesis employs water and does not require any toxic solvents [45]. Green methods for the synthesis of CuO NPs use bacteria [46], fungi [47], algae [48], or plants [49]. Among the plants, Tamarindus indica L. (Indian tamarind) fruit possesses many pharmacologically important properties and are used to control infection, fever, diarrhea, jaundice, etc.

The present work reports the isolation and identification of bacteria from a burn wound and a urinary catheter. The resistance profiles of the bacteria are evaluated and the possibility of synergistically using amoxyclav with $\mathrm{CuO}$ NPs is investigated for the ability to mitigate biofilm formation by targeting EPS formation. Moreover, the minimum inhibitory concentration (MIC) and minimum bactericidal concentration (MBC) of the T. indica fruit extract, amoxyclav, and CuO NPs are assessed against the isolated bacteria. The synergistic combination of amoxyclav and CuO NPs is investigated by the checkerboard method and a time-kill assay. In addition to the effect on planktonic cells, the effect on biofilm formation and protective EPSs is also investigated in the present study. Finally, the effect of CuO NPs on fibroblast viability is assessed.

\section{Results}

\subsection{Isolation, Identification, and Antibiotic Sensitivity of Bacteria from Urinary Catheter and Burn Wound}

The main goal of the present study is to evaluate the synergistic activity of CuO NPs with amoxyclav against multidrug-resistant bacteria. Quality control strains are susceptible to all antibiotics and do not reflect the antibiotic-resistant pattern of bacteria prevalent in clinical units. So bacteria were isolated from a burn wound and a urinary catheter of a hospitalized patient in Sivakasi, India's fireworks headquarters. The bacteria from the urinary catheter and burn wound were identified by $16 \mathrm{~S}$ ribosomal RNA(rRNA) sequencing as Proteus mirabilis and Staphylococcus aureus, as shown in Figure 1.

(a) Urinary catheter

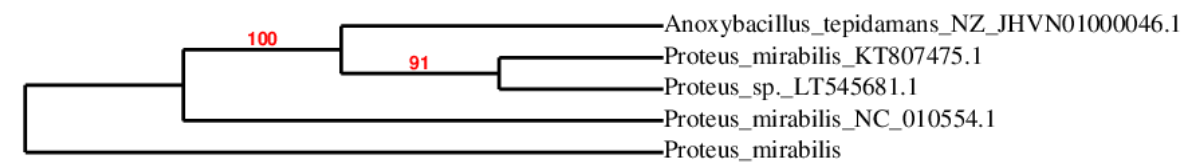

(b) Burn wound

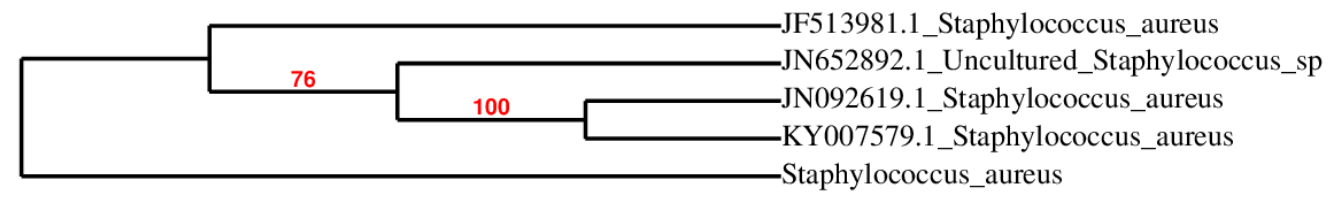

Figure 1. Phylogenetic tree of the bacterial isolate. (a) Urinary catheter; (b) burn wound.

\subsection{Susceptibility of Isolates to Antibiotics}

Investigating the sensitivity of isolates to antibiotics is essential for proper antibiotic therapy. The susceptibility of the isolated bacteria to different classes of antibiotics was assessed, and the results are presented in Table 1. The lowest susceptibility to amoxicillin ( $\beta$-lactam class) was shown by $S$. aureus, with an inhibition zone of $3 \pm 0.03 \mathrm{~mm}$. Similarly, P. mirabilis exhibited very low susceptibility to amoxicillin. When the combination of amoxicillin with clavulanic acid (amoxyclav) was used, the inhibition zone was increased to $10 \pm 0.05 \mathrm{~mm}$ and $12 \pm 0.08 \mathrm{~mm}$ against $P$. mirabilis and $S$. aureus, respectively. Even though the inhibition zone was greater than with amoxicillin alone, it was still within the resistance zone as per the Clinical and Laboratory Standards Institute [50]. The highest inhibition was exhibited by gentamicin (aminoglycoside), with an inhibition zone of $25 \pm 0.07 \mathrm{~mm}$ and 
$28 \pm 0.08 \mathrm{~mm}$ with $P$. mirabilis and $S$. aureus, respectively. The inhibition zone shown by azithromycin (macrolide) was $8 \pm 0.04 \mathrm{~mm}$ and $12 \pm 0.07 \mathrm{~mm}$ against $P$. mirabilis and $S$. aureus, respectively. The bacteria were designated as susceptible or resistant to an antibiotic based on the guidelines provided by the Clinical and Laboratory Standards Institute [50]. As the bacteria were resistant to more than one class of antibiotic, they were designated as multidrug-resistant. The resistance profile reveals an urgent need to develop strategies to combat multidrug resistance in bacteria.

Table 1. Antibiotic sensitivity profiles of bacteria.

\begin{tabular}{cccccccc}
\hline \multicolumn{7}{c}{ Diameter of Inhibition Zone (mm) } \\
\hline S. No & Bacteria & Amoxicillin & Amoxyclav & Cefixime & Ciprofloxacin & Gentamicin & Azithromycin \\
\hline 1 & P. mirabilis & $5 \pm 0.02$ & $10 \pm 0.05$ & $11 \pm 0.09$ & $13 \pm 1$ & $25 \pm 0.07$ & $8 \pm 0.04$ \\
2 & S. aureus & $3 \pm 0.03$ & $12 \pm 0.08$ & $12 \pm 0.05$ & $14 \pm 0.06$ & $28 \pm 0.08$ & $12 \pm 0.07$ \\
\hline
\end{tabular}

\subsection{Synthesis and Characterization of $\mathrm{CuO} N P s$}

The characteristics of CuO NPs are shown in Figure 2. The formation of CuO NPs (Figure 2a) was initiated by the change from the blue color of copper acetate to green, greenish-yellow, yellowish orange, and finally to the brick-red precipitation of $\mathrm{CuO} \mathrm{NPs.} \mathrm{The} \mathrm{UV-Vis} \mathrm{absorption} \mathrm{spectrum} \mathrm{of}$ $\mathrm{CuO}$ NPs displayed surface plasmon resonance (SPR) at $490 \mathrm{~nm}$, as shown in Figure 2b. Once the $\mathrm{CuO}$ NPs were formed, the size distribution of particles was analyzed in a particle size analyzer, and the result is shown in Figure 2c, showing the homogeneous distribution of particles between $40 \mathrm{~nm}$ and $50 \mathrm{~nm}$. The shape of the CuO NPs was observed to be cubes, as shown in Figure $2 \mathrm{~d}$. The elemental composition confirms the presence of $\mathrm{Cu}$, as shown in Figure 2d. The participation of various functional groups present in the T. indica fruit involved in the synthesis of CuO NPs was recorded by Fourier-transform infrared spectroscopy (FTIR), and the results are shown in Figure 2e. Peaks at $3379 \mathrm{~cm}^{-1}$ and $2936 \mathrm{~cm}^{-1}$ indicate the stretching vibrations of the $\mathrm{OH}$ and $\mathrm{CH}$ of the alkyl groups, respectively. The presence of conjugated phenolics is indicated by the peak at $2340 \mathrm{~cm}^{-1}$. In the T. indica fruit extract, the peak at $1799 \mathrm{~cm}^{-1}$ is due to the presence of aromatic structures. The peak observed at $1630 \mathrm{~cm}^{-1}$ is due to the stretching vibrations of $\mathrm{C}=\mathrm{O}$ groups. Peaks at $1417 \mathrm{~cm}^{-1}$ and $1207 \mathrm{~cm}^{-1}$ are ascribed to $\mathrm{CH}_{2}$ bending and $\mathrm{C}-\mathrm{O}-\mathrm{C}$ stretching, respectively. The peak at $682 \mathrm{~cm}^{-1}$ represents the presence of halogen-containing compounds. In $\mathrm{CuO} \mathrm{NPs}$, the presence of $\mathrm{CuO}$ is indicated by the presence of strong stretching vibrations of $\mathrm{CuO}$ at $590 \mathrm{~cm}^{-1}$. This confirms the metal oxide bond and the monoclinic phase of $\mathrm{CuO}$ NPs.It showed a peak at $2340 \mathrm{~cm}^{-1}$ that exactly matched the peak of T. indica. X-ray diffraction (XRD) shows diffraction peaks at (111), (200), (220), and (222), as shown in Figure 2f. The thermo gravimetric analysis (TGA) curve shown in Figure $2 \mathrm{~g}$ reveals a loss of $11.37 \%$ of the mass. The ultimate reduction in mass indicates a loss of moisture and organic moieties present in the prepared $\mathrm{CuO}$ NPs sample. An exothermic peak at $962.5^{\circ} \mathrm{C}$ by differential scanning calorimetry (DSC) is an indication of the monoclinic phase of CuO NPs, as shown in Figure $2 \mathrm{~h}$.

\subsection{Antibacterial Activity of $\mathrm{CuONPS}$}

Table 2 shows the concentration-dependent bactericidal activity of CuO NPs from $5 \mu \mathrm{g} / \mathrm{mL}$ to $30 \mu \mathrm{g} / \mathrm{mL}$. The maximum bactericidal activity of $29 \pm 1 \mathrm{~mm}$ was observed with $30 \mu \mathrm{g} / \mathrm{mL}$ against S. aureus. S. aureus was more susceptible to antimicrobial agents than P. mirabilis. In order to understand the antibacterial activity of the T. indica fruit extract alone, it was used as control, revealing bactericidal activity with an inhibition zone of $10 \pm 0.06 \mathrm{~mm}$ and $16 \pm 0.06 \mathrm{~mm}$ against $P$. mirabilis and S. aureus, respectively. 
a

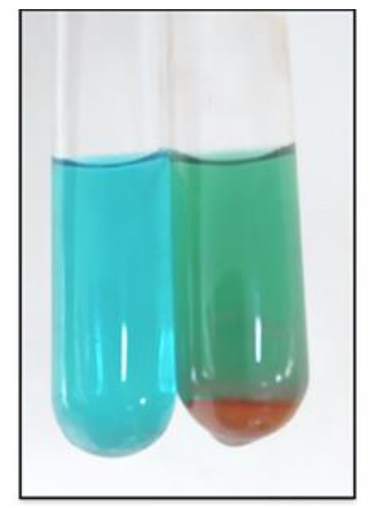

C

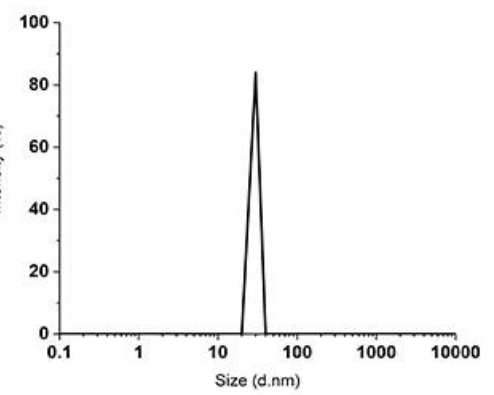

e $^{120}$

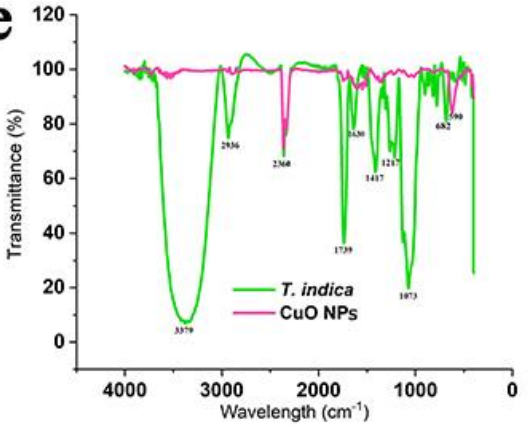

g

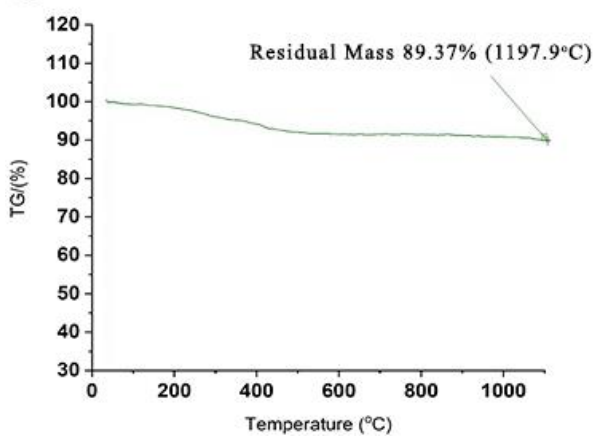

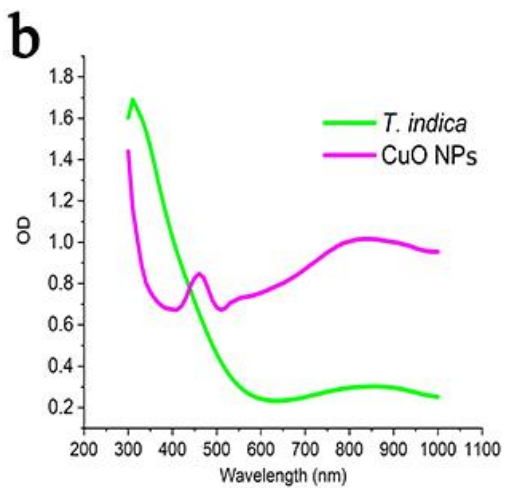

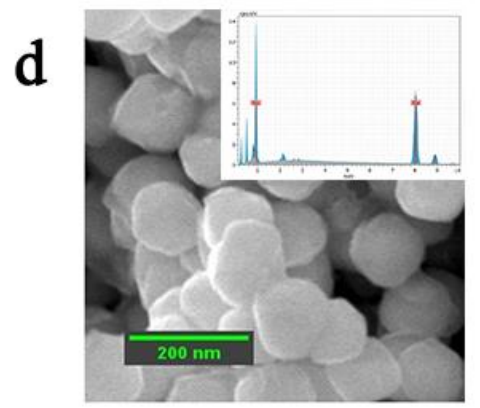

f
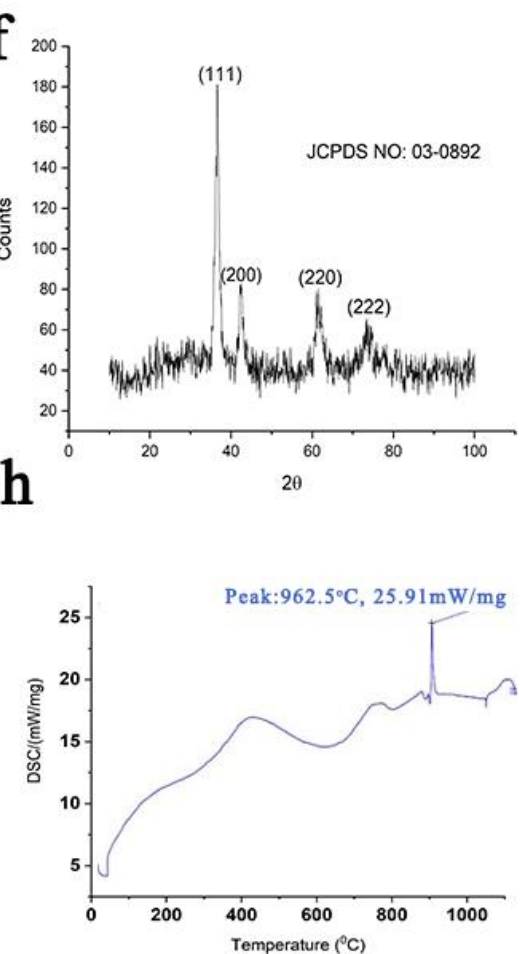

Figure 2. Synthesis and characterization of CuO NPs. (a) Formation of CuO NPs; (b) UV-Vis spectrum; (c) particle size distribution; (d) field emission scanning electron microscopic image (FESEM); (e) Fourier-transformed infrared spectrum (FTIR); (f) X-ray diffraction (XRD); (g) differential scanning calorimetry (DSC); (h) thermo gravimetric analysis (TGA). 
Table 2. Antibacterial activity of CuO NPs (diameter of inhibition zone in $\mathrm{mm}$ ).

\begin{tabular}{cccccccc}
\hline \multicolumn{7}{c}{ Concentration of CuO NPs $(\mu \mathrm{g} / \mathbf{m L})$} \\
\hline S. No. & Bacteria & $\mathbf{5}$ & $\mathbf{1 0}$ & $\mathbf{1 5}$ & $\mathbf{2 0}$ & $\mathbf{2 5}$ & $\mathbf{3 0}$ \\
\hline 1 & P. mirabilis & 5 & $10 \pm 0.06$ & $14 \pm 0.08$ & $16 \pm 0.05$ & $18 \pm 1$ & $24 \pm 1$ \\
2 & S. aureus & 8 & $14 \pm 0.07$ & $18 \pm 0.07$ & $21 \pm 0.09$ & $24 \pm 1$ & $29 \pm 1$ \\
\hline \multicolumn{7}{c}{ Concentration of T. indica fruit extract $(30 \mu \mathrm{g} / \mathrm{mL})$} \\
\hline 1 & P. mirabilis & \multicolumn{7}{c}{$10 \pm 0.06$} \\
2 & S. aureus & $16 \pm 0.06$ \\
\hline
\end{tabular}

\subsection{MIC and $M B C$}

Once the bactericidal activity was confirmed by diffusion assay, the minimum concentration required to inhibit bacterial growth was evaluated by determining the minimum inhibitory concentration (MIC) and minimum bactericidal concentration (MBC), and the results are shown in Table 3. As the fruit extract of T. indica was used to synthesize CuO NPs, the MIC and MBC of the extract were also quantified. The MIC and MBC of the fruit extract against P. mirabilis were $1000 \mu \mathrm{g} / \mathrm{mL}$ and $4000 \mu \mathrm{g} / \mathrm{mL}$, respectively. The fruit extract had an MIC and MBC of $800 \mu \mathrm{g} / \mathrm{mL}$ and $3200 \mu \mathrm{g} / \mathrm{mL}$, respectively, against S. aureus. The MIC and MBC of amoxyclav were $70 \mu \mathrm{g} / \mathrm{mL}$ and $140 \mu \mathrm{g} / \mathrm{mL}$, respectively, against $P$. mirabilis and $50 \mu \mathrm{g} / \mathrm{mL}$ and $100 \mu \mathrm{g} / \mathrm{mL}$, respectively, against $S$. aureus.

Table 3. Antibacterial activity of amoxyclav and CuO NPs.

\begin{tabular}{cccccccc}
\hline \multicolumn{3}{c}{ P. mirabilis } & \multicolumn{3}{c}{ S. aureus } \\
\hline S. No. & $\begin{array}{c}\text { Antibacterial } \\
\text { Activity }\end{array}$ & Amoxyclav & CuO NP & $\begin{array}{c}\text { T. indica } \\
\text { Fruit Extract }\end{array}$ & Amoxyclav & CuO NP & $\begin{array}{c}\text { T. indica } \\
\text { Fruit Extract }\end{array}$ \\
\hline 1 & MIC $(\mu \mathrm{g} / \mathrm{mL})$ & 70 & 30 & 1000 & 50 & 20 & 800 \\
2 & $\mathrm{MBC}(\mu \mathrm{g} / \mathrm{mL})$ & 140 & 60 & 4000 & 100 & 40 & 3200 \\
\hline
\end{tabular}

\subsection{Synergistic Interaction between Amoxyclav and $\mathrm{CuO} N$ Ps against Bacteria}

The combination of amoxyclav and $\mathrm{CuO}$ NPs in different ratios and its impact on fractional inhibitory concentration (FIC) and fractional inhibitory concentration index (FICI) are represented in Table 4. It can be inferred from the table that the FIC of both amoxyclav and CuO NPs decreased significantly at synergistic concentrations. When amoxyclav and $\mathrm{CuO}$ NPs were used in synergistic combination, the MIC was reduced 15.9-fold and 2-fold, respectively, for P. mirabilis. The synergistic combination reduced the MIC of amoxyclav and CuO NPs 32-fold and 2-fold, respectively, for S. aureus. Above $17.5 \mu \mathrm{g} / \mathrm{mL}$, amoxyclav exhibited additive activity with $\mathrm{CuO}$ NPs against $P$. mirabilis. The results obtained from the checkerboard assay proved the synergistic activity of $\mathrm{CuO} N P$ s with $\beta$-lactam antibiotics through the isobologram depicted in Figure 3. MICA and MICB are the MIC of amoxyclav and $\mathrm{CuO}$ NPs, respectively. MICAX and MICBX are the MIC of amoxyclav and CuO NPs in synergistic combination, respectively. 
Table 4. Fractional inhibitory concentration index (FICI) of amoxyclav and CuO NPs.

\begin{tabular}{cccccc}
\hline \multicolumn{7}{c}{ P. mirabilis } \\
\hline $\begin{array}{c}\text { Amoxyclav } \\
(\mu \mathrm{g} / \mathrm{mL})\end{array}$ & $\begin{array}{c}\mathbf{C u O ~ N P} \\
(\mu \mathrm{g} / \mathbf{m L})\end{array}$ & $\begin{array}{c}\text { FIC of } \\
\text { Amoxyclav }\end{array}$ & FIC of CuO NP & FICI & Interaction \\
\hline 4.4 & 15 & 0.062 & 0.25 & 0.267 & Synergistic \\
8.8 & 7.5 & 0.125 & 0.126 & 0.251 & Synergistic \\
17.5 & 3.8 & 0.25 & 0.063 & 0.313 & Synergistic \\
35 & 1.9 & 0.5 & 0.031 & 0.531 & Additive \\
\hline & & & S. aureus & & \\
\hline 1.56 & 10 & 0.03 & 0.5 & 0.503 & Additive \\
3.15 & 5 & 0.06 & 0.25 & 0.31 & Synergistic \\
6.25 & 2.5 & 0.12 & 0.125 & 0.225 & Synergistic \\
12.5 & 1.25 & 0.24 & 0.06 & 0.31 & Synergistic \\
\hline
\end{tabular}

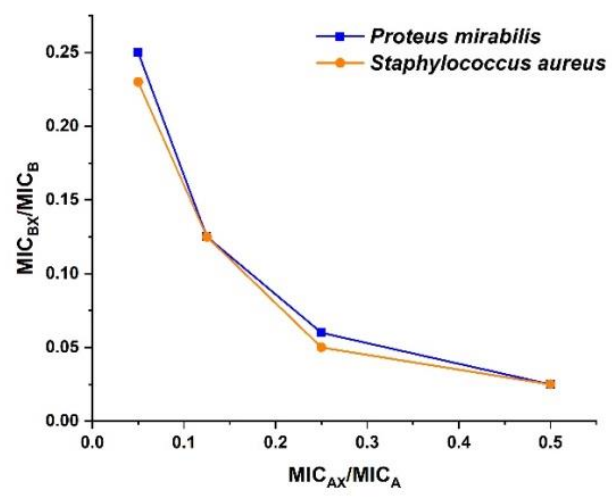

Figure 3. Synergy between amoxyclav and CuO NPs.

\subsection{Time-Kill Assay}

Upon determining the synergistic combination of amoxyclav and $\mathrm{CuO}$ NPs, the combination was investigated for its time-dependent bactericidal activity. The results of the experiment are shown in Figure 4 . With the passing of time from $4 \mathrm{~h}$ to $48 \mathrm{~h}$, the reduction in the bacterial population was less with amoxyclav. However, when used in the synergistic combination with $\mathrm{CuO}$ NPs, a very significant reduction to $4 \log$ colony forming units (CFU) was observed at $4 \mathrm{~h}$. As the time proceeded to $12 \mathrm{~h}$, it was further reduced to $2.5 \log$ CFU. At $24 \mathrm{~h}$, the bacteria were completely cleared. Amoxyclav and $\mathrm{CuO}$ NPs reduced the bacteria to $2.5 \log$ CFU and $0.75 \log$ CFU, respectively. The results demonstrated the effective control of multidrug-resistant pathogens by the synergistic combination of amoxyclav and $\mathrm{CuO}$ NPs. The time-kill assay showed the efficacy of the synergistic combination on the complete inhibition of $P$. mirabilis and S. aureus within $20 \mathrm{~h}$ and $24 \mathrm{~h}$, respectively, whereas amoxyclav and $\mathrm{CuO}$ NPs did not inhibit P. mirabilis and S. aureus until $48 \mathrm{~h}$.
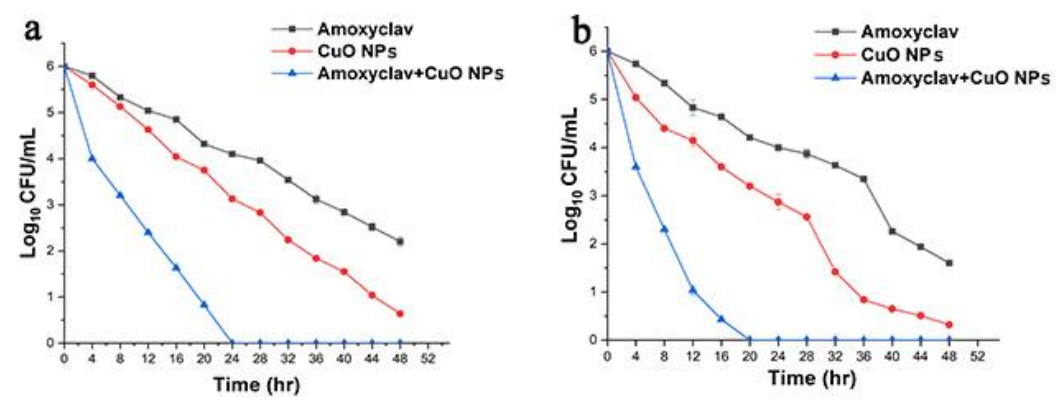

Figure 4. Time-dependent destruction of bacteria by amoxyclav and CuO NPs on (a) P. mirabilis; and (b) S. aureus. 


\subsection{Effect of Amoxyclav and $\mathrm{CuO}$ NPs on Biofilm Formation}

The synergistic combination of amoxyclav and CuO NPs was assessed for its inhibitory effect on biofilm formation by P. mirabilis and S. aureus. The results are presented in Figure 5. Amoxyclav inhibited $19 \%$ of $P$. mirabilis biofilm and $35 \%$ of $S$. aureus biofilm. The synergistic combination of amoxyclav with $\mathrm{CuO}$ NPs significantly reduced biofilm formed by P. mirabilis and S. aureus by $85 \%$ and 93\%, respectively. Biofilm and planktonic cells of $P$. mirabilis and S. aureus showed higher susceptibility to $\mathrm{CuO}$ NPs and amoxyclav in synergistic combination.

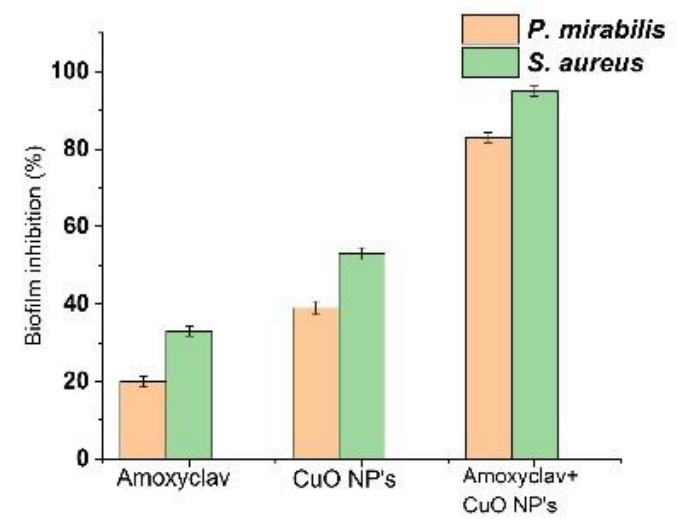

Figure 5. Inhibition of biofilm formation by amoxyclav and $\mathrm{CuO}$ NPs.

\subsection{Effect of Amoxyclav and CuO NPs on EPS Formation}

EPS serves as a barrier to the entry of chemotherapeutic agents. It protects the biofilm community from the host defense. The effect of amoxyclav and $\mathrm{CuO}$ NPs on reducing biofilm is shown in Figure 6. In the control, the concentration of proteins was $130.4 \mu \mathrm{g} / \mathrm{mL}$, which was reduced to 104, 78, and $15.7 \mu \mathrm{g} / \mathrm{mL}$ in the presence of amoxyclav, CuO NPs, and the synergistic combination of amoxyclav and $\mathrm{CuO}$ NPs, respectively. In addition to proteins, carbohydrates were also present in EPS. Carbohydrates were remarkably reduced from $113 \mu \mathrm{g} / \mathrm{mL}$ in the control to $10.5 \mu \mathrm{g} / \mathrm{mL}$ in the synergistic combination. Similarly, the concentration of DNA was also reduced in the synergistic combination treatment.
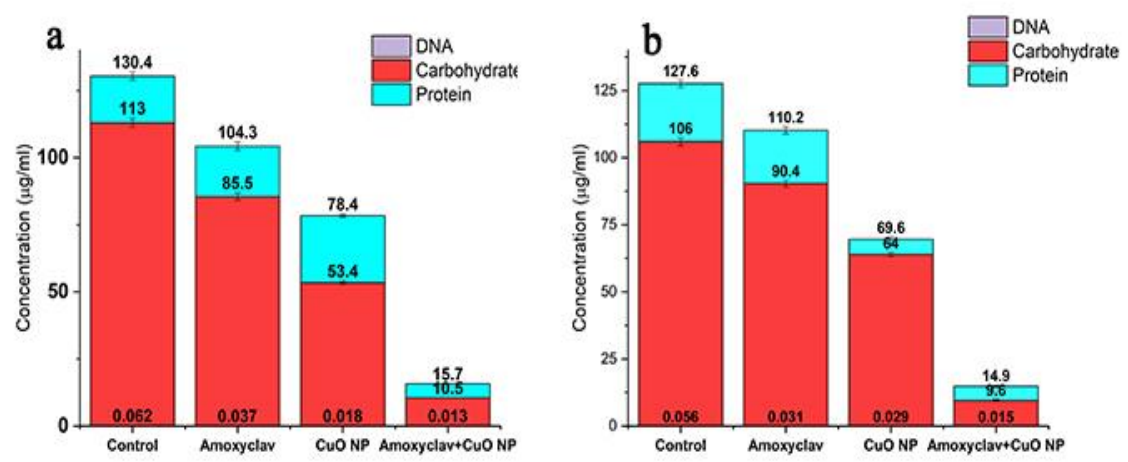

Figure 6. Inhibition of extracellular polymeric substance (EPS) formation by amoxyclav and $\mathrm{CuO}$ (a) P. mirabilis; and (b) S. aureus.

\subsection{Effect of $\mathrm{CuO}$ NPs on Viability of Human Dermal Fibroblasts}

The effect of $\mathrm{CuO}$ NPs on the viability of human dermal fibroblasts ( $\mathrm{HiFi}^{\mathrm{TM}}$ Human Adult Dermal Fibroblast-HiMedia, Mumbai, India) was evaluated, and the results are shown in Table 5 and Figure 7. The viability of the control was $100 \%$. With reference to the control, CuO NPs showed $99.47 \%$ viability. The cells cultured in the presence of $\mathrm{CuO}$ NPs showed normal morphology and no cytopathic effect was observed. This confirms that $\mathrm{CuO}$ NPs are safe for human application. 
Table 5. Impact of CuO NPs on viability of human dermal fibroblast cells.

\begin{tabular}{ccc}
\hline S. No. & Treatment & Viability (\%) \\
\hline 1 & Control & 100 \\
2 & CuO NPs $(30 \mu \mathrm{g} / \mathrm{mL})$ & 99.47 \\
\hline
\end{tabular}

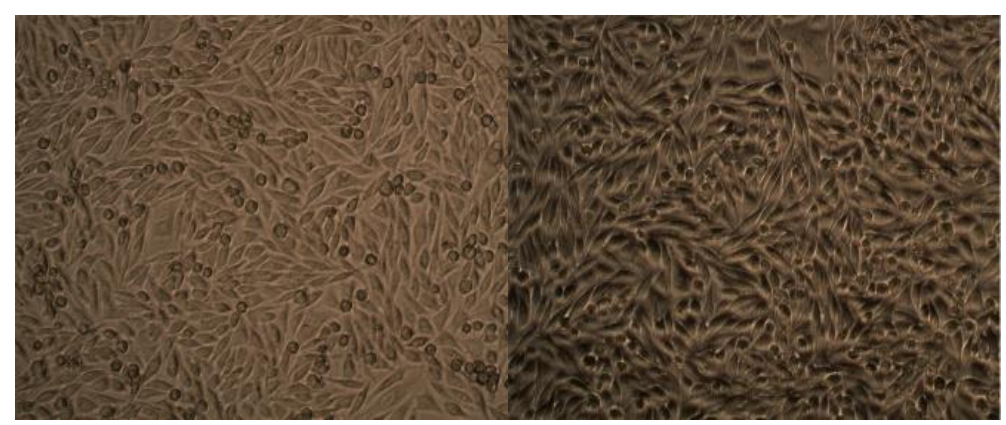

(a)

(b)

Figure 7. Effect of CuO NPs on the viability of human dermal fibroblasts: (a) control; (b) CuO NPs.

\section{Discussion}

Chronic wounds are infected by different types of pathogens. S. aureus is the predominant gram-positive organism reported in burn wounds [51]. P. mirabilis and Escherichia coli are the dominant agents of urinary tract infections [25]. The present study was focused on re-potentiating amoxyclav by synergistically combining it with $\mathrm{CuO}$ NPs due to its multiple modes of action against bacteria. Controlled synthesis of $\mathrm{CuONPs}$ by biological methods was reported [52]. Nanocubes were synthesized at $75^{\circ} \mathrm{C}$ within $10 \mathrm{~min}$ through a sequence of color changes as shown in Figure 8. During these chemical reactions, copper ions were released from copper acetate and reduced by the reducing groups present in the fruit extract of $T$. indica [51,52]. Red precipitate indicated the formation of CuO NPs [53]. At $70{ }^{\circ} \mathrm{C}$, the reaction was accelerated, leading to the formation of nanocubes. SPR at shorter wavelengths confirmed the smaller size of the CuO NPs [51]. The peak was attributed to the band gap transition of the $\mathrm{CuO}$ NPs. The fruit of $T$. indica is a rich source of flavonoids, alkaloids, and many aromatic compounds that are potent antibacterial agents [54]. Studies by Ieven et al. [54] reported that T. indica fruit has a higher concentration of secondary metabolites than stem and leaves. These secondary metabolites, when capped onto $\mathrm{CuO}$ NPs, can augment the antibacterial activity of the CuO NPs. FTIR data confirmed the presence of various functional groups of compounds in the fruit extract of T. indica and $\mathrm{CuO}$ NPs synthesized using the fruit. Peaks of conjugated polyphenols were present in both T. indica fruit and CuO NPs synthesized using it [55]. The presence of aromatic compounds was confirmed by the FTIR peak. The data indicate that $T$. indica contains a variety of phenolic compounds that play a major role in the formation of $\mathrm{CuO}$ NPs. The presence of conjugated phenolics in the extract of T. indica was supported by Zaibunnisa, et al. [56]. Polyphenolics such as catechin, epicatechin, taxifolin, apigenin, eriodictyol, luteolin, and naringenin are some of the flavonoids reported to be present in T. indica [57]. They serve as stabilizing and capping agents responsible for the well-dispersed synthesis of copper nanocubes. All nanocubes were complete without any truncation. The cubes showed smooth margins and uniform distribution. The process is energetically efficient and does not require extreme purification steps in downstream processing, as it uses no solvent except water. 


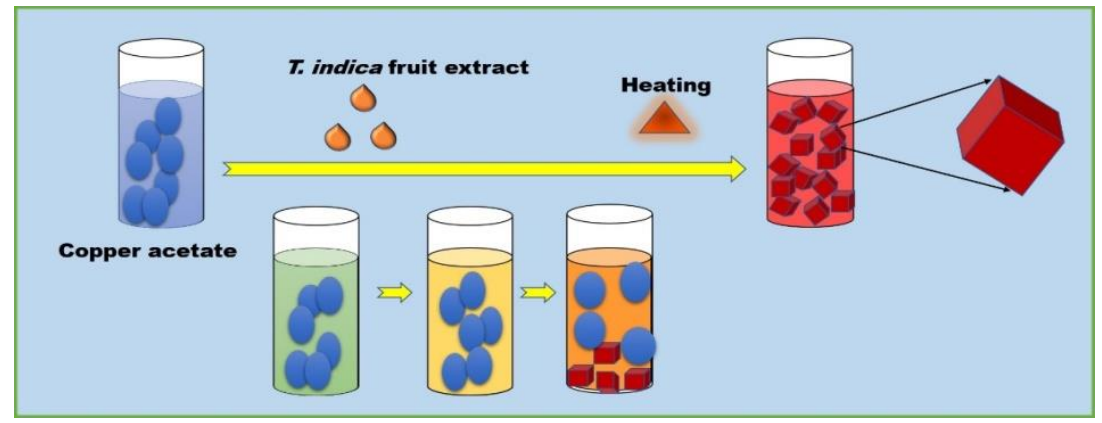

Figure 8. Mechanism of CuO NPs synthesis.

Ordered cubic-shaped $\mathrm{CuO}$ NPs revealed their well-dispersed size and shape. The asymmetric peak of $\mathrm{CuO}$ NPs was confirmed by the presence of a peak at $590 \mathrm{~cm}^{-1}$ [58]. The high packing efficiency of self-assembled nanocubes was supported in earlier studies [59]. Nanocubes with high packing density are preferable for drug delivery and interaction with cells and biomolecules [60]. The nanocube has a preference for 111 planes over other planes. These results coincide with the observations of Liu et al. [61]. The monoclinic phase of $\mathrm{CuO}$ NPs corroborates with the observations of Topnani et al. [58]. Cube-shaped structures provide greater contact area than spherical nanoparticles for interaction with bacteria. The more contact points there are, the greater the bactericidal activity. Studies by Kolhatkar et al., support the greater surface area of nanocubes over other shapes [62]. The thermal properties of $\mathrm{CuO}$ NPs were used to show the presence of compounds other than CuO NP.

The miniaturization of $\mathrm{CuO}$ at nanoscale provides high surface area and reactivity to interact with bacteria [63]. Phenolic compounds from the fruit of $T$. indica capped the nanocubes, which augment the bactericidal activity of $\mathrm{CuO}$ NPs [64]. CuO NPs create oxidative stress and generate reactive oxygen species, which is lethal to pathogens.

The synergistic combination of amoxyclav and $\mathrm{CuO}$ NPs significantly reduced biofilm in multiple ways. Amoxyclav is lethal by inhibiting bacterial cell wall biosynthesis. When used in synergistic combination, $\mathrm{CuO}$ NPs might bind with $\beta$-lactamase, making it ineffective for cleaving the $\beta$-lactam ring. In the absence of $\beta$-lactamase activity, the potency of amoxyclav was restored. The lowest concentration of amoxyclav and $\mathrm{CuONPs}$ required in the synergistic combination is due to the multiple modes of action of the agents against bacteria. $\mathrm{CuO}$ NPs interact with the negatively charged bacterial membrane by electrostatic attraction and accumulate, encapsulating the bacteria [52]. In addition, they impose oxidative stress by forming free radicals, which diffuse freely into the bacteria, causing a lethal effect. Oxidative stress oxidizes proteins, carbohydrates, and nucleic acids [65]. In addition, many different mechanisms, such as the release of copper ions, disruption of membrane integrity, and inhibition of metabolic activity, were proposed for the bactericidal activity of CuO NPs [52]. The synergistic combination was effective against both $P$. mirabilis and $S$. aureus. CuO NPs have a broad spectrum of antibacterial activity against both gram-positive and gram-negative organisms [52]. Complete elimination of biofilm formation by uropathogens was reported for CuO NPs. Similar to the present study, the broad-spectrum bactericidal activity of $\mathrm{CuO}$ NPs was documented [66]. CuO NPs were reported to be safe to eukaryotic cells. Studies by De Jong, et al. [67] reported that CuO NPs were safe in rats in amounts up to $32 \mathrm{mg} / \mathrm{kg}$. The physiological response of diarrhea was observed in rats only after administration of $512 \mathrm{mg} \mathrm{CuO} \mathrm{NPs} / \mathrm{kg}$. In the present study, the MIC of CuO NPs was $30 \mu \mathrm{g} / \mathrm{mL}$, but in the synergistic combination with amoxyclav, the FIC was a maximum of $15 \mu \mathrm{g} / \mathrm{mL}$. The effect of $\mathrm{CuO}$ NPs on fibroblasts was studied at $30 \mu \mathrm{g} / \mathrm{mL}$, showing $99.47 \%$ viability, so the concentration of $\mathrm{CuO}$ NPs in synergistic concentration with amoxyclav had no cytotoxic effect. 


\section{Materials and Methods}

\subsection{Chemicals}

All chemicals were purchased from HiMedia, Mumbai, India.

\subsection{Isolation and Identification of Bacteria}

The bacteria infecting the burn wound were isolated by swabbing the wound with a sterile swab before dressing. Immediately the swab was transported in an icebox to the laboratory for the isolation of bacteria. The swab was transferred to a blood agar medium. The plate was incubated for $18 \mathrm{~h}$ in an incubator at $37^{\circ} \mathrm{C}$. To determine whether the urinary catheter was also infected, it was collected on the day of replacement and used for the isolation of bacteria. The surface of the catheter was washed with sterile distilled water, and the catheter was opened at cross-sections. The cut catheter samples were placed in buffered saline and incubated in a shaker at $150 \mathrm{rpm}$ (revolutions per minute) for $1 \mathrm{~h}$. Bacteria transferred from the catheter bits to the saline sample were isolated by the pour plate technique. A single colony from the plate was selected and pure cultured. Genomic DNA was isolated using a HiPurA ${ }^{\mathrm{TM}}$ Bacterial Genomic DNA Purification Kit, and the $16 \mathrm{~S}$ rRNA sequence was amplified using the primers 27F 5'-AGAGTTTGATCMTGGCTCAG-3' and 1492R 5' -TACGGYTACCTTGTTACGACTT- ${ }^{\prime}$. The 16S rRNA sequencing was performed by Yaazh Xenomics, Coimbatore, India. Sequencing reactions were performed using ABI PRISM ${ }^{\circledR}$ BigDye $^{\mathrm{TM}}$ Terminator Cycle Sequencing Kits with AmpliTaq ${ }^{\circledR}$ DNA polymerase (FS enzyme) (Applied Biosystems, Thermo Fischer Scientific, Waltham, MA, USA) in an ABI $3730 \times 1$ sequencer (Applied Biosystems). Nucleotide sequences were resolved using the basic local alignment search tool on the National Center for Biotechnology Information (NCBI) website and the sequences of related taxa were retrieved. Sequence alignment was conducted and the phylogenetic tree was generated using the neighbor-joining method [68] and Molecular Evolutionary Genetics Analysis (MEGA) version 5.0-Pennsylvania State University, PA, USA [69]. Data analysis was performed on a bootstrapped set with 1000 replicates.

\subsection{Susceptibility of Bacteria to Antimicrobial Agents}

An antibiotic susceptibility test was performed by the disc diffusion method [50]. A single colony of the isolated organisms was inoculated into $2 \mathrm{~mL}$ of sterile nutrient broth separately and incubated at $37^{\circ} \mathrm{C}$ in a shaker at $120 \mathrm{rpm}$ for $12 \mathrm{~h}$. The culture was adjusted to $1 \times 10^{6} \mathrm{CFU} / \mathrm{mL}$, and $100 \mu \mathrm{L}$ of the culture was swabbed onto Mueller and Hinton agar plates (Himedia, Mumbai, India). Discs of amoxicillin $(30 \mu \mathrm{g})$, amoxyclav $(30 \mu \mathrm{g})$, ciprofloxacin $(30 \mu \mathrm{g})$, cefixime $(30 \mu \mathrm{g})$, azithromycin $(30 \mu \mathrm{g})$, and gentamicin $(50 \mu \mathrm{L})$ were used. The plates were incubated at $37^{\circ} \mathrm{C}$ for $12 \mathrm{~h}$, and then the diameter of the zone of inhibition around the well was measured. The zone of inhibition was interpreted using the standards published by the Clinical and Laboratory Standards Institute [50].

\subsection{Synthesis and Characterization of $\mathrm{CuONPs}$}

$\mathrm{CuO}$ NPs were synthesized using the aqueous extract of Tamarindus indica L. (Indian tamarind) fruit. The T. indica fruit was obtained from a local market. The fruit pulp (without seeds) was soaked in water for 60 minutes at room temperature. The aqueous extract of the fruit was prepared by extracting $10 \mathrm{~g}$ of fruit pulp with $100 \mathrm{~mL}$ of Milli-Q water at room temperature. The extract was centrifuged at 10,000 rpm for $15 \mathrm{~min}$. The supernatant was concentrated and used. The extract was centrifuged at 10,000 rpm for $15 \mathrm{~min}$. The supernatant was concentrated and used. Under heating and constant stirring, $10 \mathrm{~mL}$ of extract was slowly added to $100 \mathrm{~mL}$ of $3 \mu \mathrm{M}$ copper acetate solution. The red precipitate was separated by centrifugation at 15,000 rpm for $15 \mathrm{~min}$. The precipitate was dried and stored [70]. Visible light absorption and vibrational spectra were recorded using a UV-Vis spectrophotometer (Hitachi, Tokyo, Japan) and Fourier-transform infrared spectrophotometer (Thermo Sceintific Ltd., Waltham, MA, USA). The size of the CuO NPs was documented using a particle size analyzer. Structural and elemental analysis was captured using field emission scanning electron 
microscopy (FESEM, Carl Zeiss, Cambridge, UK) and energy dispersive spectroscopy (Bruker, Billerica, MA, USA). The crystalline behavior of copper nanoparticles was recorded using a powder X-ray diffractometer (X'Pert Pro-PANalytic-Malvern Panalytical, Almelo, The Netherlands). The thermal stability of CuO NPs was determined using DSC coupled with TGA (Netzch, Selb, Germany).

\subsection{Determination of Antibacterial Activity, MIC, and $M B C$}

The bactericidal activity of CuO NPs $(30 \mu \mathrm{g})$ was determined by well diffusion. The MIC and $\mathrm{MBC}$ of $\mathrm{CuO}$ NPs, and amoxyclavh were determined by 2-fold serial dilution in broth [71]. The experiment was performed in flat-bottomed 96-well plates. The cultures of P. mirabilis and S. aureus grown overnight were adjusted to $10^{8} \mathrm{CFU} / \mathrm{mL}$. The plate was maintained with broth as a negative control. Growth control was maintained with the broth and the culture without any antimicrobial agents. In one of the wells, $100 \mu \mathrm{L}$ of amoxyclav $(2040 \mu \mathrm{g} / \mathrm{mL})$ was added. In a separate well, $100 \mu \mathrm{L}$ of $\mathrm{CuO} N$ Ps $(1920 \mu \mathrm{g} / \mathrm{mL})$ was added. From these wells, 2-fold dilutions were done serially in the subsequent wells to attain $2040 \mu \mathrm{g} / \mathrm{mL}$ to $4.35 \mu \mathrm{g} / \mathrm{mL}$ amoxyclav and $1920 \mu \mathrm{g} / \mathrm{mL}$ to $3.75 \mu \mathrm{g} / \mathrm{mL}$ CuO NPs. Then $100 \mu \mathrm{L}$ each of P. mirabilis and S. aureus $\left(10^{8} \mathrm{CFU} / \mathrm{mL}\right)$ was added to the respective plates. The plates were incubated at $37^{\circ} \mathrm{C}$ for $12 \mathrm{~h}$. The concentration of the antimicrobial agent in the well where no visible growth was observed was considered as the MIC. Then $100 \mu \mathrm{L}$ of the sample from the respective MIC wells and the three preceding wells were taken and plated onto nutrient agar to determine the MBC. The concentration of the antimicrobial agent where no colony was found in the plate was recorded as the $\mathrm{MBC}$.

\subsection{Time-Kill Assay}

The synergy between amoxyclav and CuO NPs was determined by a time-kill assay [72]. To determine the time-dependent lethal effect of amoxyclav and CuO NPs on P. mirabilis and S. aureus, the culture grown overnight was adjusted to $1 \times 10^{8} \mathrm{CFU} / \mathrm{mL}$. Then $25 \mathrm{~mL}$ of Luria-Bertani (LB) broth was inoculated with $1 \mathrm{~mL}$ each of $P$. mirabilis and S. aureus in separate conical flasks, and $30 \mu \mathrm{g} / \mathrm{mL}$ each of $\mathrm{CuO}$ NPs and amoxyclav were added to the flasks. The flasks were kept in an incubator-cum-shaker at $37^{\circ} \mathrm{C}$. Growth control was maintained in the same manner except for the addition of any antimicrobial agent. Viable colony count was measured by sampling the culture at $4 \mathrm{~h}$ intervals for $48 \mathrm{~h}$. Synergistic interaction was determined by the reduction in the number of viable cells by more than 2 logs between the single agent and the combination of agents. A reduction of less than 2 logs indicated no difference.

\subsection{Synergistic Interaction between Amoxyclav and $\mathrm{CuO} N \mathrm{NS}$}

The synergistic interaction between two or more drugs was determined by checkerboard assay, where the test compounds were serially diluted alone and in all combinations of drugs [73]. The fractional inhibitory concentration (FIC) of amoxyclav and CuO NPs was determined by 2-fold serial dilution from $0.5 \times$ MIC to $0.015 \times$ MIC. To determine FICI, amoxyclav was varied in a descending manner and $\mathrm{CuO}$ NPs were decreased vertically. In the plates, negative control was maintained with the broth and the growth control was maintained with culture alone without any antimicrobial agent for comparison. The wells other than the negative control were loaded with $10 \mu \mathrm{L}$ of $1 \times 10^{6} \mathrm{CFU} / \mathrm{mL}$ of $P$. mirabilis and S. aureus in separate plates. The plates were incubated at $37^{\circ} \mathrm{C}$ for $24 \mathrm{~h}$. The wells where bacterial growth was reduced by more than $80 \%$ were considered as the MIC. The combined effect of the drugs was concluded from the FICI value: FICI = MIC in combination/MIC alone of amoxyclav + MIC in combination/MIC alone of CuO NPs. The data were interpreted according to the instructions of the European Committee on Antimicrobial Susceptibility Testing [74].

\subsection{Effect of Amoxyclav and $\mathrm{CuO}$ NPs on Biofilm Formation}

To evaluate biofilm inhibition by antibiotics and $\mathrm{CuO}$ NPs, biofilm was formed in 96-well flat-bottomed polystyrene microtiter plates in triplicate [75]. For this, $10 \mu \mathrm{L}$ each of $\left(1 \times 10^{6} \mathrm{CFU} / \mathrm{mL}\right)$ P. mirabilis and S. aureus was inoculated onto $190 \mu \mathrm{L}$ of LB in separate wells, then $10 \mu \mathrm{L}$ of CuO NPs 
$(30 \mu \mathrm{g} / \mathrm{mL})$ was added to the wells. Negative control was maintained without an antimicrobial agent and positive control was maintained with amoxyclav and CuO NPs. The plates were incubated at $37^{\circ} \mathrm{C}$ for $24 \mathrm{~h}$. The medium was aspirated in order to remove the planktonic cells and gently washed thrice with phosphate-buffered saline. Then $200 \mu \mathrm{L}$ of $2 \%$ crystal violet solution was added to the wells and left undisturbed for $20 \mathrm{~min}$. Excess crystal violet stain was removed and washed using a buffer. The crystal violet staining the biofilm was solubilized by $125 \mu \mathrm{L}$ of $30 \%$ acetic acid. The color was measured using a microplate reader (BIO-RAD, Hercules, CA, USA) at $570 \mathrm{~nm}$.

\subsection{Effect of Amoxyclav and CuO NP on EPS Formation}

Biofilm was formed in 96-well plates in triplicate, as mentioned above [75]. After biofilm formation, the cells were not stained with crystal violet. Instead, the attached cells were collected by vigorous mixing and washing with a $2 \mathrm{mM}$ phosphate buffer at $\mathrm{pH}$. The suspension was vortexed for $30 \mathrm{~min}$ and an equal volume of $30 \%$ ethylenediaminetetraacetic acid (EDTA) was added. The mixture was incubated in a shaker for $3 \mathrm{~h}$ at $4{ }^{\circ} \mathrm{C}$. The sample was centrifuged at 15,000 rpm for $15 \mathrm{~min}$. The supernatant was filtered, sterilized $(0.22 \mu \mathrm{m})$, and dialyzed in a dialysis bag with a $3500 \mathrm{Da}$ cutoff against Milli-Q water to separate the high-molecular-mass compounds. The sample was used for the quantification of carbohydrates, proteins, and DNA. The total carbohydrates were quantified by the phenol-sulfuric acid method [76]. Proteins were determined by Lowry's method [77]. DNA was quantified by the dye-binding method [78].

\section{Effect of CuO NPs on Viability of Human Dermal Fibroblasts}

The effect of CuO NPs on the viability of fibroblasts was quantified by (3-[4, methylthiazol-2-yl]-2, 5-diphenyl tetrazolium bromide (MTT) dye assay [79]. This test is based on the reduction of water-soluble yellow MTT dye to water-insoluble purple formazan crystals by live cells. The cells $(500 \mu \mathrm{L})$ were seeded onto wells at a density of $1 \times 10^{6}$ cells $/ \mathrm{mL}$ in Dulbecco's modified eagle medium supplemented with $10 \%$ fetal bovine serum. The plates were incubated in a humidified $\mathrm{CO}_{2}$ incubator maintained at $37^{\circ} \mathrm{C}$ for $24 \mathrm{~h}$. After $24 \mathrm{~h}, 30 \mu \mathrm{g}$ of $\mathrm{CuO}$ NPs was added to the wells. A control well was maintained without $\mathrm{CuO}$ NPs. After $48 \mathrm{~h}$, the medium was removed and replaced with a fresh medium containing MTT $(5 \mathrm{mg} / \mathrm{mL})$ and incubated in the dark for $4 \mathrm{~h}$. The purple formazan crystals were dissolved in dimethylsulfoxide and read at $570 \mathrm{~nm}$ in an ELISA reader (Thermo Sceintific Ltd., Waltham, MA, USA). The viability of cells was calculated with reference to the absorbance of control cells using the formula:

$$
\text { Viability }(\%)=(\text { Control OD }) /(\text { Test OD }) \times 100
$$

Author Contributions: The concept was conceived by M.R. and R.C.A.S. The work was carried out by R.C.A.S. and H.P.N. The data were analyzed by M.R., R.C.A.S. and H.P.N. The manuscript was written by all the authors.

Funding: This research was funded by DST Nano Mission, India (Ref: NM/NS/01/2015 (G) dated 30 May 2016). The funders had no role in the design of the study; in the collection, analysis, or interpretation of data; in the writing of the manuscript; or in the decision to publish the results.

Acknowledgments: The authors acknowledge Nano Mission for the financial support for the execution of the project and the laboratory support provided by the Head of the Department of Biotechnology, Principal and Management Board, Mepco Schlenk Engineering College (Autonomous), Tamil Nadu, India. The authors thank Preetha Mohan, Department of Biotechnology, and Muthu Selvi, Department of Mechanical Engineering, Mepco Schlenk Engineering College, Sivakasi, India, for their contribution to XRD analysis, and Selva Kumar, Centre of Excellence for Industrial Textile (PSGTECHS COE INDUTECH), Coimbatore, India, for his technical assistance in recording FESEM and Energy dispersive X-ray spectroscopic analysis.

Conflicts of Interest: The authors declare no conflict of interest. 


\section{References}

1. Bernardi, S.; Continenza, M.A.; Al-Ahmad, A.; Karygianni, L.; Follo, M.; Filippi, A.; Macchiarelli, G. Streptococcus spp. and Fusobacterium nucleatum in tongue dorsum biofilm from halitosis patients: A fluorescence in situ hybridization (FISH) and confocal laser scanning microscopy (CLSM) study. New Microbiol. 2019, 42, 108-113. [PubMed]

2. Seviour, T.; Derlon, N.; Dueholm, M.S.; Flemming, H.C.; Girbal-Neuhauser, E.; Horn, H.; Kjelleberg, S.; van Loosdrecht, M.C.M.; Lotti, T.; Malpei, M.F.; et al. Extracellular polymeric substances of biofilms: Suffering from an identity crisis. Water Res. 2019, 151, 1-7. [CrossRef]

3. Zippel, B.; Neu, T.R. Characterization of glycoconjugates of extracellular polymeric substances in tufa-associated biofilms by using fluorescence lectin-binding analysis. Appl. Environ. Microbiol. 2011, 77, 505-516. [CrossRef] [PubMed]

4. Yonezawa, H.; Osaki, T.; Hojo, F.; Kamiya, S. Effect of Helicobacter pylori biofilm formation on susceptibility to amoxicillin, metronidazole and clarithomycin. Microb. Pathog. 2019. [CrossRef] [PubMed]

5. Khatoon, Z.; McTiernan, C.D.; Suuronen, E.J.; Mah, T.F.; Alarcon, E.I. Bacterial biofilm formation on implantable devices and approaches to its treatment and prevention. Heliyon 2018, 4, e01067. [CrossRef] [PubMed]

6. Henly, E.L.; Dowling, J.A.R.; Maingay, J.B.; Lacey, M.M.; Smith, T.J.; Forbes, S. Biocide Exposure Induces Changes in Susceptibility, Pathogenicity, and Biofilm Formation in Uropathogenic Escherichia coli. Antimicrob. Agents Chemother. 2019, 63. [CrossRef] [PubMed]

7. Boisvert, A.A.; Cheng, M.P.; Sheppard, D.C.; Nguyen, D. Microbial Biofilms in Pulmonary and Critical Care Diseases. Ann. Am. Thorac. Soc. 2016, 13, 1615-1623. [CrossRef] [PubMed]

8. Liu, Y.; Naha, P.C.; Hwang, G.; Kim, D.; Huang, Y.; Simon-Soro, A.; Jung, H.I.; Ren, Z.; Li, Y.; Gubara, S.; et al. Topical ferumoxytol nanoparticles disrupt biofilms and prevent tooth decay in vivo via intrinsic catalytic activity. Nat. Commun. 2018, 9, 2920. [CrossRef]

9. Jung, C.J.; Hsu, R.B.; Shun, C.T.; Hsu, C.C.; Chia, J.S. AtlA Mediates Extracellular DNA Release, Which Contributes to Streptococcus mutans Biofilm Formation in an Experimental Rat Model of Infective Endocarditis. Infect. Immun. 2017, 85. [CrossRef] [PubMed]

10. Hamilos, D.L. Biofilm Formations in Pediatric Respiratory Tract Infection Part 2: Mucosal Biofilm Formation by Respiratory Pathogens and Current and Future Therapeutic Strategies to Inhibit Biofilm Formation or Eradicate Established Biofilm. Curr. Infect. Dis. Rep. 2019, 21, 8. [CrossRef]

11. Brady, R.A.; Leid, J.G.; Calhoun, J.H.; Costerton, J.W.; Shirtliff, M.E. Osteomyelitis and the role of biofilms in chonic infection. FEMS Immunol. Med. Microbiol. 2008, 52, 13-22. [CrossRef] [PubMed]

12. Kiedrowski, M.R.; Gaston, J.R.; Kocak, B.R.; Coburn, S.L.; Lee, S.; Pilewski, J.M.; Myerburg, M.M.; Bomberger, J.M. Staphylococcus aureus Biofilm Growth on Cystic Fibrosis Airway Epithelial Cells Is Enhanced during Respiratory Syncytial Virus Coinfection. mSphere 2018, 3. [CrossRef] [PubMed]

13. Chakraborty, P.; Kumar, A. The extracellular matrix of mycobacterial biofilms: Could we shorten the treatment of mycobacterial infections? Microb. Cell 2019, 6, 105-122. [CrossRef] [PubMed]

14. Kackar, S.; Suman, E.; Kotian, M.S. Bacterial and fungal biofilm formation on contact lenses and their susceptibility to lens care solutions. Indian J. Med. Microbiol. 2017, 35, 80-84. [CrossRef] [PubMed]

15. Mala, R.; Annie Aglin, A.; Ruby Celsia, A.S.; Geerthika, S.; Kiruthika, N.; VazagaPriya, C.; Srinivasa Kumar, K. Foley catheters functionalised with a synergistic combination of antibiotics and silver nanoparticles resist biofilm formation. IET Nanobiotechnol. 2017, 11, 612-620. [CrossRef] [PubMed]

16. Rieger, U.M.; Raschke, G.F.; Frei, R.; Djedovic, G.; Pierer, G.; Trampuz, A. Role of bacterial biofilms in patients after reconstructive and aesthetic breast implant surgery. J. Long-Term Eff. Med. Implants 2014, 24, 131-138. [CrossRef] [PubMed]

17. Connaughton, A.; Childs, A.; Dylewski, S.; Sabesan, V.J. Biofilm Disrupting Technology for Orthopedic Implants: What's on the Horizon? Front. Med. (Lausanne) 2014, 1, 22. [CrossRef]

18. Somogyi-Ganss, E.; Chambers, M.S.; Lewin, J.S.; Tarrand, J.J.; Hutcheson, K.A. Biofilm on the tracheoesophageal voice prosthesis: Considerations for oral decontamination. Eur. Arch. Otorhinolaryngol. 2017, 274, 405-413. [CrossRef]

19. Elgharably, H.; Hussain, S.T.; Shestha, N.K.; Blackstone, E.H.; Pettersson, G.B. Current Hypotheses in Cardiac Surgery: Biofilm in Infective Endocarditis. Semin. Thorac. Cardiovasc. Surg. 2016, 28, 56-59. [CrossRef] 
20. Subhadra, B.; Kim, D.H.; Woo, K.; Surendran, S.; Choi, C.H. Control of Biofilm Formation in Healthcare: Recent Advances Exploiting Quorum-Sensing Interference Strategies and Multidrug Efflux Pump Inhibitors. Materials 2018, 11. [CrossRef]

21. Dasgupta, M.K. Biofilms and infection in dialysis patients. Semin. Dial. 2002, 15, 338-346. [CrossRef]

22. Toba, F.A.; Akashi, H.; Arrecubieta, C.; Lowy, F.D. Role of biofilm in Staphylococcus aureus and Staphylococcus epidermidis ventricular assist device driveline infections. J. Thorac. Cardiovasc. Surg. 2011, 141, 1259-1264. [CrossRef] [PubMed]

23. Algburi, A.; Comito, N.; Kashtanov, D.; Dicks, L.M.T.; Chikindas, M.L. Control of Biofilm Formation: Antibiotics and Beyond. Appl. Environ. Microbiol. 2017, 83. [CrossRef]

24. Ellis, S.; Lin, E.J.; Tartar, D. Immunology of Wound Healing. Curr. Dermatol. Rep. 2018, 7, 350-358. [CrossRef]

25. Albu, S.; Voidazan, S.; Bilca, D.; Badiu, M.; Truta, A.; Ciorea, M.; Ichim, A.; Luca, D.; Moldovan, G. Bacteriuria and asymptomatic infection in chonic patients with indwelling urinary catheter: The incidence of ESBL bacteria. Medicine 2018, 97, e11796. [CrossRef]

26. Narayanan, A.; Nair, M.S.; Muyyarikkandy, M.S.; Amalaradjou, M.A. Inhibition and Inactivation of Uropathogenic Escherichia coli Biofilms on Urinary Catheters by Sodium Selenite. Int. J. Mol. Sci. 2018, 19. [CrossRef] [PubMed]

27. Jakovljevic, M.; Al Ahdab, S.; Jurisevic, M.; Mouselli, S. Antibiotic Resistance in Syria: A Local Problem Turns Into a Global Theat. Front. Public Health 2018, 6, 212. [CrossRef] [PubMed]

28. Veiga, R.P.; Paiva, J.A. Pharmacokinetics-pharmacodynamics issues relevant for the clinical use of beta-lactam antibiotics in critically ill patients. Crit. Care 2018, 22, 233. [CrossRef]

29. Wolny-Koladka, K.; Lenart-Boron, A. Antimicrobial resistance and the presence of extended-spectrum beta-lactamase genes in Escherichia coli isolated from the environment of horse riding centers. Environ. Sci. Pollut. Res. Int. 2018, 25, 21789-21800. [CrossRef] [PubMed]

30. Site, N.-M.n.-A.A. Penicillin Production. Available online: https://www.news-medical.net/health/PenicillinProduction.aspx (accessed on 11 June 2019).

31. Fallone, C.A.; Moss, S.F.; Malfertheiner, P. Reconciliation of Recent Helicobacter pylori Treatment Guidelines in a Time of Increasing Resistance to Antibiotics. Gastroenterology 2019. [CrossRef]

32. Adnan, S.; Paterson, D.L.; Lipman, J.; Kumar, S.; Li, J.; Rudd, M.; Roberts, J.A. Pharmacokinetics of beta-lactam antibiotics in patients with intra-abdominal disease: A structured review. Surg. Infect. 2012, 13, 9-17. [CrossRef] [PubMed]

33. Al-Sabbagh, A.; Moss, S.; Subhedar, N. Neonatal necrotising enterocolitis and perinatal exposure to co-amoxyclav. Arch. Dis. Child. Fetal Neonatal Ed. 2004, 89, F187. [CrossRef] [PubMed]

34. Assimakopoulos, S.F.; Karamouzos, V.; Lefkaditi, A.; Sklavou, C.; Kolonitsiou, F.; Chistofidou, M.; Fligou, F.; Gogos, C.; Marangos, M. Triple combination therapy with high-dose ampicillin/sulbactam, high-dose tigecycline and colistin in the treatment of ventilator-associated pneumonia caused by pan-drug resistant Acinetobacter baumannii: A case series study. Infez Med. 2019, 27, 11-16.

35. Pilmis, B.; Jullien, V.; Tabah, A.; Zahar, J.R.; Brun-Buisson, C. Piperacillin-tazobactam as alternative to carbapenems for ICU patients. Ann. Intensive Care 2017, 7, 113. [CrossRef]

36. Shirley, M. Ceftazidime-Avibactam: A Review in the Treatment of Serious Gram-Negative Bacterial Infections. Drugs 2018, 78, 675-692. [CrossRef] [PubMed]

37. Tancawan, A.L.; Pato, M.N.; Abidin, K.Z.; Asari, A.S.; Thong, T.X.; Kochhar, P.; Muganurmath, C.; Twynholm, M.; Barker, K. Amoxicillin/Clavulanic Acid for the Treatment of Odontogenic Infections: A Randomised Study Comparing Efficacy and Tolerability versus Clindamycin. Int. J. Dent. 2015, 2015, 472470. [CrossRef]

38. Chandki, R.; Banthia, P.; Banthia, R. Biofilms: A microbial home. J. Indian Soc. Periodontol. 2011, 15, 111-114. [CrossRef] [PubMed]

39. Odeh, L.H.; Talib, W.H.; Basheti, I.A. Synergistic effect of thymoquinone and melatonin against breast cancer implanted in mice. J. Cancer Res. Ther. 2018, 14, S324-S330. [CrossRef] [PubMed]

40. Wen, W.; Lowe, G.; Roberts, C.M.; Finlay, J.; Han, E.S.; Glackin, C.A.; Dellinger, T.H. Pterostilbene Suppresses Ovarian Cancer Growth via Induction of Apoptosis and Blockade of Cell Cycle Progression Involving Inhibition of the STAT3 Pathway. Int. J. Mol. Sci. 2018, 19. [CrossRef] [PubMed] 
41. Lopez-Carrizales, M.; Velasco, K.I.; Castillo, C.; Flores, A.; Magana, M.; Martinez-Castanon, G.A.; Martinez-Gutierrez, F. In Vitro Synergism of Silver Nanoparticles with Antibiotics as an Alternative Treatment in Multiresistant Uropathogens. Antibiotics 2018, 7. [CrossRef]

42. Tran, C.D.; Makuvaza, J.; Munson, E.; Bennett, B. Biocompatible Copper Oxide Nanoparticle Composites from Cellulose and Chitosan: Facile Synthesis, Unique Structure, and Antimicrobial Activity. ACS Appl. Mater. Interfaces 2017, 9, 42503-42515. [CrossRef] [PubMed]

43. Zhou, J.; You, Z.; Xu, W.; Su, Z.; Qiu, Y.; Gao, L.; Yin, C.; Lan, L. Microwave irradiation directly excites semiconductor catalyst to produce electric current or electron-holes pairs. Sci. Rep. 2019, 9, 5470. [CrossRef] [PubMed]

44. Silva, N.; Ramirez, S.; Diaz, I.; Garcia, A.; Hassan, N. Easy, Quick, and Reproducible Sonochemical Synthesis of CuO Nanoparticles. Materials 2019, 12. [CrossRef] [PubMed]

45. Zohora, N.; Kandjani, A.E.; Orth, A.; Brown, H.M.; Hutchinson, M.R.; Gibson, B.C. Fluorescence brightness and photostability of individual copper (I) oxide nanocubes. Sci. Rep. 2017, 7, 16905. [CrossRef] [PubMed]

46. Iravani, S. Bacteria in Nanoparticle Synthesis: Current Status and Future Prospects. Int. Sch. Res. Not. 2014, 2014, 359316. [CrossRef] [PubMed]

47. Mohammed Fayaz, A.; Balaji, K.; Kalaichelvan, P.T.; Venkatesan, R. Fungal based synthesis of silver nanoparticles-an effect of temperature on the size of particles. Colloids Surf. B Biointerfaces 2009, 74, 123-126. [CrossRef]

48. Arya, A.; Gupta, K.; Chundawat, T.S.; Vaya, D. Biogenic Synthesis of Copper and Silver Nanoparticles Using Green Alga Botryococcus braunii and Its Antimicrobial Activity. Bioinorg. Chem. Appl. 2018, 2018, 7879403. [CrossRef]

49. Miri, A.; Sarani, M.; Rezazade Bazaz, M.; Darroudi, M. Plant-mediated biosynthesis of silver nanoparticles using Prosopis farcta extract and its antibacterial properties. Spectrochim. Acta A Mol. Biomol. Spectrosc. 2015, 141, 287-291. [CrossRef] [PubMed]

50. Kassim, A.; Omuse, G.; Premji, Z.; Revathi, G. Comparison of Clinical Laboratory Standards Institute and European Committee on Antimicrobial Susceptibility Testing guidelines for the interpretation of antibiotic susceptibility at a University teaching hospital in Nairobi, Kenya: A cross-sectional study. Ann. Clin. Microbiol. Antimicrob. 2016, 15, 21. [CrossRef]

51. Gunalan, S.; Sivaraj, R.; Venckatesh, R. Aloe barbadensis Miller mediated green synthesis of mono-disperse copper oxide nanoparticles: Optical properties. Spectrochim. Acta A Mol. Biomol. Spectrosc. 2012, 97, 1140-1144. [CrossRef]

52. Azam, A.; Ahmed, A.S.; Oves, M.; Khan, M.S.; Memic, A. Size-dependent antimicrobial properties of CuO nanoparticles against Gram-positive and -negative bacterial strains. Int. J. Nanomed. 2012, 7, 3527-3535. [CrossRef] [PubMed]

53. DeAlba-Montero, I.; Guajardo-Pacheco, J.; Morales-Sanchez, E.; Araujo-Martinez, R.; Loredo-Becerra, G.M.; Martinez-Castanon, G.A.; Ruiz, F.; Compean Jasso, M.E. Antimicrobial Properties of Copper Nanoparticles and Amino Acid Chelated Copper Nanoparticles Produced by Using a Soya Extract. Bioinorg. Chem. Appl. 2017, 2017, 1064918. [CrossRef] [PubMed]

54. Ieven, M.; Vanden Berghe, D.A.; Mertens, F.; Vlietinck, A.; Lammens, E. Screening of higher plants for biological activities. I. Antimicrobial activity. Planta Med. 1979, 36, 311-321. [PubMed]

55. Available online: www.chem.ucla.edu (accessed on 6 June 2019).

56. Zaibunnisa, A.H.; Aini Marhanna, M.N.A.; Ainun Atirah, M. Characterisation and solubility study of $\gamma$-cyclodextrin and $\beta$-carotene complex. Int. Food Res. J. 2011, 18, 1061-1065.

57. Sudjaroen, Y.; Haubner, R.; Wurtele, G.; Hull, W.E.; Erben, G.; Spiegelhalder, B.; Changbumrung, S.; Bartsch, H.; Owen, R.W. Isolation and structure elucidation of phenolic antioxidants from Tamarind (Tamarindus indica L.) seeds and pericarp. Food Chem. Toxicol. 2005, 43, 1673-1682. [CrossRef] [PubMed]

58. Topnani, N.; Kushwaha, S.; Athar, T. Wet Synthesis of Copper Oxide Nanopowder. Int. J. Green Nanotechnol. Mater. Sci. Eng. 2009, 1, M67-M73. [CrossRef]

59. Lee, Y.H.; Lay, C.L.; Shi, W.; Lee, H.K.; Yang, Y.; Li, S.; Ling, X.Y. Creating two self-assembly micro-environments to achieve supercrystals with dual structures using polyhedral nanoparticles. Nat. Commun. 2018, 9, 2769. [CrossRef] 
60. Karimi, M.; Zangabad, P.S.; Mehdizadeh, F.; Malekzad, H.; Ghasemi, A.; Bahami, S.; Zare, H.; Moghoofei, M.; Hekmatmanesh, A.; Hamblin, M.R. Nanocaged platforms: Modification, drug delivery and nanotoxicity. Opening synthetic cages to release the tiger. Nanoscale 2017, 9, 1356-1392. [CrossRef]

61. Liu, Y.; Zhang, Y.; Chen, J.; Pang, H. Copper metal-organic framework nanocrystal for plane effect nonenzymatic electro-catalytic activity of glucose. Nanoscale 2014, 6, 10989-10994. [CrossRef]

62. Kolhatkar, A.G.; Chen, Y.T.; Chinwangso, P.; Nekrashevich, I.; Dannangoda, G.C.; Singh, A.; Jamison, A.C.; Zenasni, O.; Rusakova, I.A.; Martirosyan, K.S.; et al. Magnetic Sensing Potential of Fe3O4 Nanocubes Exceeds That of Fe3O4 Nanospheres. ACS Omega 2017, 2, 8010-8019. [CrossRef]

63. Suresh, A.K.; Pelletier, D.A.; Doktycz, M.J. Relating nanomaterial properties and microbial toxicity. Nanoscale 2013, 5, 463-474. [CrossRef] [PubMed]

64. Marslin, G.; Siram, K.; Maqbool, Q.; Selvakesavan, R.K.; Kruszka, D.; Kachlicki, P.; Franklin, G. Secondary Metabolites in the Green Synthesis of Metallic Nanoparticles. Materials 2018, 11. [CrossRef] [PubMed]

65. Lu, J.; Wang, Z.; Cao, J.; Chen, Y.; Dong, Y. A novel and compact review on the role of oxidative stress in female reproduction. Reprod. Biol. Endocrinol. 2018, 16, 80. [CrossRef] [PubMed]

66. Agarwala, M.; Choudhury, B.; Yadav, R.N. Comparative study of antibiofilm activity of copper oxide and iron oxide nanoparticles against multidrug resistant biofilm forming uropathogens. Indian J. Microbiol. 2014, 54, 365-368. [CrossRef] [PubMed]

67. De Jong, W.H.; De Rijk, E.; Bonetto, A.; Wohlleben, W.; Stone, V.; Brunelli, A.; Badetti, E.; Marcomini, A.; Gosens, I.; Cassee, F.R. Toxicity of copper oxide and basic copper carbonate nanoparticles after short-term oral exposure in rats. Nanotoxicology 2019, 13, 50-72. [CrossRef] [PubMed]

68. Carrasco, G.; Valdezate, S.; Garrido, N.; Villalon, P.; Medina-Pascual, M.J.; Saez-Nieto, J.A. Identification, typing, and phylogenetic relationships of the main clinical Nocardia species in spain according to their gyrB and rpoB genes. J. Clin. Microbiol. 2013, 51, 3602-3608. [CrossRef] [PubMed]

69. Tamura, K.; Peterson, D.; Peterson, N.; Stecher, G.; Nei, M.; Kumar, S. MEGA5: Molecular evolutionary genetics analysis using maximum likelihood, evolutionary distance, and maximum parsimony methods. Mol. Biol. Evol. 2011, 28, 2731-2739. [CrossRef] [PubMed]

70. Sharma, P.; Pant, S.; Dave, V.; Tak, K.; Sadhu, V.; Reddy, K.R. Green synthesis and characterization of copper nanoparticles by Tinospora cardifolia to produce nature-friendly copper nano-coated fabric and their antimicrobial evaluation. J. Microbiol. Methods 2019, 160, 107-116. [CrossRef]

71. Tippayawat, P.; Phomviyo, N.; Boueroy, P.; Chompoosor, A. Green synthesis of silver nanoparticles in aloe vera plant extract prepared by a hydrothermal method and their synergistic antibacterial activity. PeerJ 2016, 4, e2589. [CrossRef]

72. Loo, Y.Y.; Rukayadi, Y.; Nor-Khaizura, M.A.; Kuan, C.H.; Chieng, B.W.; Nishibuchi, M.; Radu, S. In Vitro Antimicrobial Activity of Green Synthesized Silver Nanoparticles Against Selected Gram-negative Foodborne Pathogens. Front. Microbiol. 2018, 9, 1555. [CrossRef]

73. Sharma, N.; Jandaik, S.; Kumar, S. Synergistic activity of doped zinc oxide nanoparticles with antibiotics: Ciprofloxacin, ampicillin, fluconazole and amphotericin B against pathogenic microorganisms. An. Acad. Bras. Cienc. 2016, 88, 1689-1698. [CrossRef] [PubMed]

74. EUCAST. MIC and Zone Diameter Distributions and ECOFFs. Available online: http://www.eucast.org/mic_ distributions_and_ecoffs/(accessed on 14 June 2019).

75. Haney, E.F.; Trimble, M.J.; Cheng, J.T.; Valle, Q.; Hancock, R.E.W. Critical Assessment of Methods to Quantify Biofilm Growth and Evaluate Antibiofilm Activity of Host Defence Peptides. Biomolecules 2018, 8. [CrossRef] [PubMed]

76. Dubois, M.; Gilles, K.; Hamilton, J.K.; Rebers, P.A.; Smith, F. A colorimetric method for the determination of sugars. Nature 1951, 168, 167. [CrossRef] [PubMed]

77. Lowry, O.H.; Rosebrough, N.J.; Farr, A.L.; Randall, R.J. Protein measurement with the Folin phenol reagent. J. Biol. Chem. 1951, 193, 265-275. [PubMed]

78. Douthart, R.J.; Burnett, J.P.; Beasley, F.W.; Frank, B.H. Binding of ethidium bromide to double-stranded ribonucleic acid. Biochemistry 1973, 12, 214-220. [CrossRef] [PubMed] 
79. Skladanowski, M.; Golinska, P.; Rudnicka, K.; Dahm, H.; Rai, M. Evaluation of cytotoxicity, immune compatibility and antibacterial activity of biogenic silver nanoparticles. Med. Microbiol. Immunol. 2016, 205, 603-613. [CrossRef]

Sample Availability: No samples of the compounds are available from the authors.

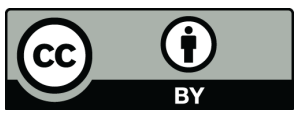

(C) 2019 by the authors. Licensee MDPI, Basel, Switzerland. This article is an open access article distributed under the terms and conditions of the Creative Commons Attribution (CC BY) license (http://creativecommons.org/licenses/by/4.0/). 